\title{
VII.-NEW BOOKS.
}

\author{
Platoniom. By Padr Emorz Morz. Princeton University Press, \\ 1917. Pp. ix, 307.
}

This is a difficult book to review, and, for reasons which will appesr, it is not quite easy for me to be fair to it. I must, however, try my best; for I cannot be taken as acquiescing in the account which the writer gives of my views. In the frst place, it must be eaid that Mr. More takes Platonism seriously, and that he has tried to give a personal interpretation of it instead of eerving up the old formulas afresh. These are great merits. In the second place it must be eaid that he writes well and is always interesting, even when he appears to be wrong. On the other hand, he is too apt to dispose of diffeulties by a mere ipse dixit, and he has not a very firm grasp of the history of Greek thought. It makes a bad impression, for instance, when we find on page 5 that he regards the ascetic Pyrrho as a hedonist. We know that Pyrrbo looked upon virtue not only as the highest, but as the only good, and that his sceptioism consisted maginly in his fiew that everything else, pleasure included, was indifferent. Such things are not negligible; for we are told in the Preface that the aim of this volume is "to lay the foundation for a series of studies on the origin and early environment of Ohristianity, and on such more modern moveinents as tho revival of philosophic religion in the seventeenth century and of romanticism in the eighteenth". These are great themes, and Mr. More has certain qualifications for déaling with them; but it is certain that he will not do so adequately till he has learnt to fiod more in Neoplatonism than "theosophical speculation," and till he sees the insppropriateness of, calling Plotinus and Proclus "the barbarians of Alezandria "."

The Socrates of this work is not by any means the mere lay figure to which we have been accustomed, but a real human being. In the main, Mr. More frankly identifies the "historical" and the Platonic Socrates, and he sees (p. 254) that the meeting of the young Socrates with Parmenides and Zeno must be regarded "not only as a fact but as one to which Socrates was fond of alluding". He also distinguishes clearly betwoen the "sceptical" or "rationalist" side of Socratic thought and the "mystical" or "intuitive," and he endearours to do justice to both of them. That being so, it is difficult to see how he came to credit Prof. Taylor and myeelf with the view that Socrates was a "pure mystic," and that all the rationslism in the dialogues comes from Plato (pp. 11, 12). I am sure that Prof. Taylor has never said anything of the sort, and I

1 On page 279 we read that "There (i.e., at Alexandria) its chief exponent was Plotinus," from which it appears that Mr. More really thinks that Plotinus taught at Alexandria. He was perhaps born in Fgypt, and he studied in his younger days at Alexandris, but he taught at Rome, and it was there that he developed his philosophical aystem. Proclus taught at Athens and had nothing to do with Alexandria. 
know that I have said just the opposite. I have preferred, indeed, to use the Greok terms "enthusiasm" and "irony" for the two eiements in the character of -Socrates, ${ }^{2}$ and I have protested against any account which ignores either of them. I have also pointed out that, however much Soorates had been influenced by the religious movement of his jouth, and however fully he may have possessed the mystical temperament, his attitude towards particular Orphic or Pythagorean beliefs and practices is always one of kindly but humorous aloofness." The "rationalist" always has the last word. In fact it is Mr. More who attaches an exaggerated importance to one feature of the "mystioism" of Socrates, the "divine sign " or "voice," and, as this is closely bound up with what I take to be the main contention of his book, it will be neceseary to say something sbout it.

To those who realise the influence of Pythagoreanism on Socrates the "sign" presents no grent difficulty, and the humorous way in which Socrates sometimes epeaks of it is quite in keeping with his genersl attitude to such things. We are clearly bound to accept, as Mr. More does, the explicit statement of the Apology that it only gave negative advice. It nover told Socrutes to do anything. This, however, is hardly sufficient justification for the contention that, to the true Platonist, spiritual intuition always means inhibition. It will bo best to give this. remarkable doctrine in the writer's own words. He sajs (p. 272) :-

To the true Platonist the divine opirit, though it may be called, and is, the hidden source of beauty and order and joy, yet always, when it speaks directly in the human breast, makes itself heard as an inhibition; like the guide of Socrates, it never in its own proper voice commands to do, but only to refrain.

Now this implies that the "divine sign" was the guide of Sncrates in questions of right and wrong, and that it is to be identified with the spiritual intuition which enabled him to transcend his scepticisin. That is a view which can be refuted from the Apology itself. There we aro told that the "sign" constantly cerme to him on quite trivial oecasions (rávv ėi orexpois) and opposed his doing something he was about to do. A good example of this is found in the kithydemus (272e), where Socrates was about to lcave the company and the divine sign opposed him, so that he sat down again. Nor is there a single case where it restrains Socrates from action on grounds of what Mr. More calls morality; it has to do solely with the results of acts in themselves indifierent, and it is justified solely on prudential grounds. The passage where Socrates tells his judges that it was tho "sign" which mado him abstain from politicul lifo is no exception; for he immediately goes on to say that the "sign" was quite right in ite opposition, since, if he had gone in for politics, he would long since have been put to death (Apol., 31d). In fact, Plato. agrees with Xenophon at least in this, that the "divine sign" was a kind of divination ( $\mu a v r(x \eta$ ) which gave premonitions of undesirable results. It has nothing to do with right or wrong, but only with such matters as we might decide by tossing up. Of course it is impossible to believe it was really the "sign" that kept Soerates out of politics. That is only the high irony of the apeech. We are not told that it was this mysterious voice that warned him to take no part in the arrest of Leon of Salamis or to refuse to put an illegal motion to the vote at the trial of the

\footnotetext{
1 Greek Philosophy, Part I., \$\$ 101, 102.

See especially my edition of the Phcedo, Introd., p. 1v. 50, and the notes there referred to.
} 
generals. These were abstentions, indeed, but not of the kind for which Socrates required any mysterious sanotion. On the other hand, he ineists with complete seriousness that he had received certain very positive commands indeed from "the god" (or "God," as his hearers might choose to understand the words). It was "the god" and not the "divine sign " that bade Bocrates negleot his private affiirs and devote his whole life to the conversion of his fellow-citizens by getting them to "care for their souls," and he knew that it would be wrong to disobey this command, even if it were to cost him his life, as it did. He represents himself as a soldier of God, and military commands are not solely or mainly

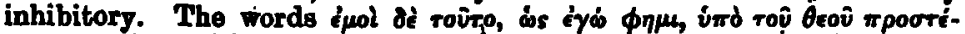


view, and it would be eayy to add to them. It needed no mysterious voice to tell Socrales what was right for him to do, and the inhibitory sign is a half-belief of which ho does not spenk quite seriously. It had nothing to do with the knowledge which is also goodness because it is knowledge of what is good for man's soul. No doubt Socrates thought there might bo something in it, and it generslly, "so he tolls us, turned out right, but it was in no sense the guide of his life.

I have dwelt on this because I believe it goes to the root of the matter, but I would not leave the impression that there is nothing to be learnt froin what Mr. More says of Socrates. On the contrary, much of what he writes is true and well put. Ho has also sorne instructive thinge to sity of the later dialogues, and he rightly insists on the importence of the Laws. I cannot, however, make out what he supposes my view of the secind part of the Parmenides to be. He himself mnintains that all the arguments are intended to lead to an impasse. That is just what I have said, though Mr. More does not mention the faet. I had even suggested that Zeno's account of the purpose of his own argumente was intended as a hint of the way we are to take the latter part of the dialogue. Mr. More was not bound in any way to mention this, except that he falls foul of me, in a passage which I do not understand, for having turned a negative into a positive conclusion, a thing I had certainly no intention of doing and which I cannot soe that I have done. Mr. More's own interpretation does not appear to differ fundementally from mine, and I have surely left no one any excuse for supposing that I regard the arguments otherwise then as reductions to the absurd.'

Mr. More will have it that there was no Platonio philosophy beyond that contained in the dialogues. If that is so, Plato must havo differed from most other thinkers. It is surely very unusual for a man to tind expression for his ripest thoughts in his writings, and that will be specially true of one who had learnt from Soorates to ha such stress on the living word. In such cases we expect to hear a good deal from the philosopher's pupils which wo look for in vain in his published works. Now Mr. More inakes no attempt to explain what Aristotle says about Plato. To be sure, Aristotle's criticisms are a trouble to all of us, and he would be a bold man who would say that he fully understood them. No doubt it is pretty clear that A ristotle either could not or would not understand certain parts of Plato's teaching, but he had been a member of the Academy for twenty years, and when he tells us distinctly that Plato taught certain things which are certainly not to be found in his dialogues, are we to disbelieve him ? There were scores of people living

1 Mr. More originally published this criticism in the Philosophical Review (xxy., 135 sq.). I did not reply, because I thought ho had mado a slip, as we all do sometimes. However he has now reprinted it verbatim. 
who could have contradicted him if he had invented these things, but as a matter of fact he is confirmed on one of the most important pointe by another member of the Academy, Hermodorus. In general, I ghould say that Mr. More's trentment of such questions is seriously weakened by his failure to make clear to himself the nature of the Academy and the Lyceum and the relation between theri. For instance, he actually thipks well of Teichmüller's madcap suggestion that cortain pasagges in. the Laros are a reply to Aristotle's Ethics. Surely it is certain that the course of lectures for which the Ethics formed a basis cannot have been delivered till after Plato's death, and as good as certain that it was not published till after the death of Aristotle himself. On the other hand, Mr. More will have.nothing to say to the Epistles; but, after all, the Epistles exist, and, if we are going to dismiss them as forgeries, we are bound to give some plausible acount of how they came to be and when. Prof. Shorey once spoke of a "Philonic or neo-Platonic tendency " in one of the Epistles,' but that was an inadvertence, seeing that Cicero had resd the Epistles, which mesns that they existed long before there were any Neoplatonists and even before Philo. In fact those who have argued recently against the genuineness of the Epistles have mostly been forced to admit that they must have been written by a contemporary of Plato himself, and this seems a very difficult thesis to maintain. The main criticism I would make, however, is that a work on Platonism, especially if it is to be a foundation for a series of studies on its influence in later days, must itself be founded in a clearer viow of the historical conditions in which Platonism arose and in which it was handed down to succeeding generations. Apart from that, it will be built on the sand.

JOHA BURSET.

Studies in the History of Ideas. Edited by the Department of Philosophy of Columbia University. Vol. I. New York : Columbia University Press, 1918. Pp. 272.

It is, of course, a common-place that to appreciate any doctrine whatsoever, one needs first of all to determine as precisely as possible what it meant to its originator. And to do this, we need, as the editors of the present volume say in their Prefatory Note, to exeroise "historical imagination ". Even in pure mathematics the work of any one great man can hardly be understood without some such acquaintance with his bistorical milieu, and in philosophy, where more than anywhere else formules seom capable of almost unlimited variation in their meaning, such knowledge is absolutely indispensable. The task of the contributors to this volume is thus a very important one, most important, perhaps, in a country like the United States when the eense of historical continuity wich the whole of past civilisation is perhaps inevitably less vivid than among the lesding peoples of Europe. In the main the volume is therefore to be highly commended, even where the esseyists do not seem to be saying anything particularly novel. Even where one of the writere is explaining what a specialist student will probably know alresdy, it is an advantage to have historical truths about philosophical idess summsrised briefly and expressed in a style likely to appeal to the ordinary educuted man of good intelligeuce. Of course it would not be denied that the value of the exercise of imagination commended by the editore depends upon the qualification expressed by the adjective "historical ".

${ }^{1}$ Olassical Philology, x. (1915), p. 87. 